\title{
Health risk assessment model for lead contaminated soil in Bagega Community, Nigeria
}

\author{
*11ALABA, OC; ${ }^{2}$ OPAFUNSO, ZO; ${ }^{3}$ AGYEI, G \\ ${ }^{1}$ Department of Mining Engineering, Federal University of Technology, Akure, Nigeria \\ ${ }^{2,3}$ Department of Mining Engineering, University of Mines \& Technology, Tarkwa Ghana \\ Corresponding Author e-mail: ocalaba@futa.edu.ng; zoopafunso@umat.edu.gh
}

\begin{abstract}
The study developed health risk assessment model for lead contaminated soil in Bagega community using United States Environmental Protection Agency (US EPA) and Canadian Standards Association (CAS) standard procedures. Questionnaires were used to investigate the background causes and exposure pathways of lead contaminated soil. Soil samples were collected at five different sites and cancer health risk values were estimated using equations proposed by US EPA. The results show that $84.0 \%$ of the respondents agreed that the causes of lead poisoning in the study area were due to the activities of artisanal gold miners. The major exposure pathways to lead contaminated soil are ingestion, dermal contact and inhalation while the soil ingestion generates high cancer risk, dermal contact generates low cancer risk and that of inhalation was insignificant when compared with $1.00 \mathrm{E}-06(\mathrm{mg} / \mathrm{kg} / \mathrm{day}) \mathrm{WHO}$ cancer risk standard. The mean cancer health risk value for combined exposure pathway is ranged from $1.49 \mathrm{E}-03 \mathrm{mg} / \mathrm{kg} / \mathrm{day}$ to $5.99 \mathrm{E}-03$ $\mathrm{mg} / \mathrm{kg} / \mathrm{day}$. The study established that lead contaminated soil posed cancer health risk to the people of the study area.
\end{abstract}

\section{DOI: https://dx.doi.org/10.4314/jasem.v22i5.17}

Copyright: Copyright ( 12018 Alaba et al. This is an open access article distributed under the Creative Commons Attribution License (CCL), which permits unrestricted use, distribution, and reproduction in any medium, provided the original work is properly cited.

Dates: Received: 15 March 2018; Revised: 20 April 2018; Accepted: 24 April 2018

Keywords: Health risk model, exposure pathways, lead contaminated soil, soil ingestion

The prevalent news of lead poisoning through the activities of artisanal gold mining in some states in Nigeria has become a worrisome to the stakeholders across the mining sector. According to Alaba and Opafunso (2016), the first lead poison was reported in Zanfara State in 2010 while another one was reported in Niger State in 2013. The released of lead during the gold processing into the environment has resulted to potential danger to the people, which requires urgent attention to protect public health and the environment (USEPA, 1991). The first action that expert needs to execute is to develop health risk assessment model that will facilitate the selection and effectiveness of remedial options (Alaba and Adesida, 2017). The risk assessment model provides the necessary information for decision makers and ensures the allocation of the available resources in order of importance during the remediation (Taiwo and Awomeso, 2017). The risk assessment model involves estimation of the type and magnitude of the exposure compared to the chemical elements present in the soil (WHO, 1994). According to USEPA (1989), the risk assessment is multi-step procedures that comprise: data collection, exposure assessment, toxicity assessment and risk characterization.

In Bagega community, more than 200 children under the age of 5years have been reported death due to the gold processing carried out by artisanal gold miners
(MSF, 2012; Greig et al., 2014). The local methods adopted by the miners in processing gold enhanced the release of substantial amounts of lead dust which was spread across the community. The ingestion, inhalation and dermal contact of lead contaminated soil, water and food crops were responsible for the monumental death of the children (CDC, 2010; Bello et al., 2016). The environmentalists tagged the Zamfara State incident as the worst outbreak of lead poison in modern history (HRW, 2011). The study therefore developed a health risk assessment model (HRAM) that facilitates the selection and effectiveness of remedial options of the contaminated soil.

\section{MATERIAL AND METHODS}

Description of the Study Area: The study area is Bagega Community which situated in Anka Local Government Areas of Zamfara State. The location of the study area is within the coordinates $5.999 \mathrm{E}$ and $6.049 \mathrm{E} ; 11.873 \mathrm{~N}$ and $11.861 \mathrm{~N}$. The main occupation of the people in the study area is farming until recent time when artisanal gold mining becomes important socio-economic activities of the people due to rise in worldwide gold prices (JUNEP/OCHA, 2010). The major agricultural produce includes carrot, sweet potatoes, millet, guinea-corn, maize, rice, groundnuts, cotton, vegetables, tobacco and beans. 
Methodology: Questionnaire was designed for the study in order to determine the background causes of lead contaminated soil and their exposure pathways in the study area. Two hundred and fourteen (214) questionnaires were distributed to the farmers, artisanal gold miners, government agencies/NGOs and health workers. The judgment sampling procedure was used in selecting the respondents, while simple random sampling technique was used to distribute the questionnaires to the respondents. The analyses of the questionnaire were carried out using descriptive and inferential statistical analyses. The sampling of soil samples was carried out in five different areas based on their land use of which health risk assessment was carried out. The area includes: Bagega Residential Compound (BRC), Bagega Residential Garden (BRG), Bagega Village Common (BVC) Areas, Bagega Industrial Area (BIA) and Bagega Farmland Area (BFA) with their nothing and easting coordinates given in Table 1. Soil samples were collected using stratified random sampling methods in accordance with ASTM D6907 standard procedures while the concentration of lead was determined using Atomic Absorption Spectrophotometer (AAS) in accordance with ASTM D 3559 standard methods.

\begin{tabular}{cccccccccccc}
\multicolumn{10}{c}{ Table 1: Location of Soil Sample } \\
\hline Site & \multicolumn{1}{c}{ BRC } & \multicolumn{2}{c}{ BRG } & \multicolumn{2}{c}{ BVC } & \multicolumn{3}{c}{ BPA } & \multicolumn{2}{c}{ BFA } \\
ID & East & North & East & North & East & North & East & North & East & North \\
\hline 01 & 173712 & 1313334 & 173201 & 1313415 & 173416 & 1313554 & 173209 & 1313368 & 173143 & 1313894 \\
02 & 173429 & 1313395 & 173462 & 1313344 & 173733 & 1313334 & 173589 & 1313359 & 173372 & 1313935 \\
03 & 173209 & 1313138 & 173289 & 1313189 & 173431 & 1313383 & 173569 & 1313116 & 173654 & 1313721 \\
04 & 173342 & 1313214 & 173359 & 1313343 & 173281 & 1313620 & 173130 & 1313782 & 173641 & 1313558 \\
05 & 173655 & 1313335 & 173521 & 1313105 & 173224 & 1313274 & 173198 & 1313629 & 173746 & 1313497 \\
06 & 173456 & 1313327 & - & - & 173442 & 1313604 & 173347 & 1313551 & 173073 & 1313247 \\
07 & 173392 & 1313523 & - & - & 173823 & 1313412 & 173230 & 1313808 & 173010 & 1313683 \\
08 & 173270 & 1313449 & - & - & 173249 & 1313507 & 173486 & 1313272 & 173766 & 1313162 \\
09 & 173116 & 1313728 & - & - & 173512 & 1313216 & 173162 & 1313446 & - & - \\
10 & 173528 & 1313344 & - & - & 173390 & 1313693 & 173319 & 1313141 & - & - \\
11 & 173283 & 1313418 & - & - & 173320 & 1313218 & 173141 & 1313641 & - & - \\
12 & 173283 & 1313640 & - & - & 173013 & 1313561 & - & - & - & - \\
13 & 173459 & 1313166 & - & - & - & - & - & - & - & - \\
15 & 173215 & 1313571 & - & - & - & - & - & - & - & - \\
15 & 173292 & 1313548 & - & - & - & - & - & - & - \\
\hline
\end{tabular}

The cancer health risks of lead contamination in soil were estimated using equation (1) to (3) as proposed by USEPA (1991).

(a) Soil ingestion:

Cancer risk $\left(\mathrm{CR}_{\text {ingest }}\right)=\frac{\mathrm{IR}_{\mathrm{s}} * \mathrm{C}_{\mathrm{s}} * \mathrm{EF} * \mathrm{CF} * \mathrm{ED}}{\mathrm{BW} * \mathrm{AT} * 365 \text { days } / \mathrm{yr}} * \mathrm{CSF}_{\text {oral }} 1$

(b) Dermal Absorption

Cancer risk $\left(\mathrm{CR}_{\text {dermal }}\right)=\frac{\mathrm{C}_{\mathrm{s}} * \mathrm{CF} * \mathrm{SA} * \mathrm{EF} * \mathrm{ABS} * \mathrm{AF} * \mathrm{ED}}{\mathrm{BW} * \mathrm{AT} * 365 \text { days } / \mathrm{yr}} * \mathrm{CSF}_{\text {dermal }} 2$

(c) Particulate Inhalation

Cancer risk $\left(\mathrm{CR}_{\mathrm{inh}}\right)=\frac{\mathrm{C}_{\mathrm{s}} * 1 / \mathrm{PEF} * \mathrm{IR}_{\mathrm{a}} * \mathrm{ET} * \mathrm{EF} * \mathrm{ED}}{\mathrm{BW} * \mathrm{AT} * 365 \text { days } / \mathrm{yr}} * \mathrm{CSF}_{\mathrm{inh}} 3$

Where, $\mathrm{CR}=$ cancer risk for daily intake of metal (ingestion, dermal, inhalation) $[\mathrm{mg} / \mathrm{kg} /$ day $]$; $\mathrm{CSF}$ is cancer slope factor (oral, dermal, inhalation) (mg/kgday $)^{-1} ; \mathrm{IR}_{\mathrm{s}}$ is soil ingestion rate $[\mathrm{mg} / \mathrm{day}]$; $\mathrm{CF}$ is conversion factor $[1 \mathrm{E}-06, \mathrm{~kg} / \mathrm{mg}] ; \quad \mathrm{C}_{\text {soil }}$ is concentration of pollutant in soil $[\mathrm{mg} / \mathrm{kg}]$; $\mathrm{SA}$ is skin surface area available for exposure $\left(\mathrm{cm}^{2} /\right.$ event); $\mathrm{AF}$ is soil to skin adherence factor $\left(\mathrm{mg} / \mathrm{cm}^{2}\right)$; ABS is absorption factor (unitless); $\mathrm{IR}_{\mathrm{a}}$ is inhalation rate $\left(\mathrm{m}^{3} / \mathrm{hr}\right)$; PEF is soil-to-air particulate emission factor $\left(\mathrm{kg} / \mathrm{m}^{3}\right)$; ET is exposure time (hrs/day); EF is exposure frequency [days/year]; ED is exposure duration [years]; BW is body weight $[\mathrm{kg}]$; AT is average time (years); and RfD is reference dose (oral, dermal, inhalation) (mg/kg-day).
The health risk assessment model (HRAM) was developed by adopting USEPA (1991) and CAS (2001) standard procedures. The was carried out by developing conceptual health risk model during the first stage of site assessment and updated as more detailed information on the site and the nature of contamination becomes available. The development of HRAM involved technical data from various sources that: support selection of sampling locations to establish background concentrations of identified contaminants; describe the processes that determine contaminant release, migration and receptor exposure; and evaluate the risk to human or ecological receptors. This was achieved by pulling together results obtained from questionnaire analyses, laboratory analyses and health risk analyses to form a flowsheet.

\section{RESULTS AND DISCUSSION}

The result of the questionnaire shows that $84.0 \%$ of the respondents agreed that the causes of lead poisoning in the study area were due to the activities of artisanal gold miners, while $7.0 \%$ agreed that it was due to the geology of the mineral deposit and $9.0 \%$ agreed that it was caused by the materials used for processing gold as shown in Table 2 . Therefore, it can be deduced from the result that the activities of 
artisanal gold miners were responsible for lead poisoning across the study area. As a result of physical observation carried out with the support of the questionnaire, the lead release mechanism of contaminated soil was established through the methods of gold processing in the study area which include breaking and grinding, pulverization, sluicing and washing, amalgamation as shown in Figure 1. Also, Figure 2 illustrates the exposure point to lead contaminated soil in the study area. The identified exposure points are: Bagega residential compound (BRC), Bagega residential garden (BRG), Bagega village common (BVC) area, Bagega industrial area (BIA) and Bagega farmland area (BFA). Figure 3 shows the exposure pathways and the receptors of lead contaminant across the study area. The identified exposure pathways are ingestion, dermal contact and inhalation of lead dust while the major receptors of lead contamination are human being, animal and their environment.

Table 2: Causes of Lead Poisoning in Bagega Community

\begin{tabular}{lcc} 
Description of the activities & Frequency & Percent \\
\hline AGM Activities & 180 & 84.0 \\
Geology of the areas & 14 & 7.0 \\
Use of lead materials & 20 & 9.0 \\
Total & $\mathbf{2 1 4}$ & $\mathbf{1 0 0 . 0}$ \\
\hline
\end{tabular}

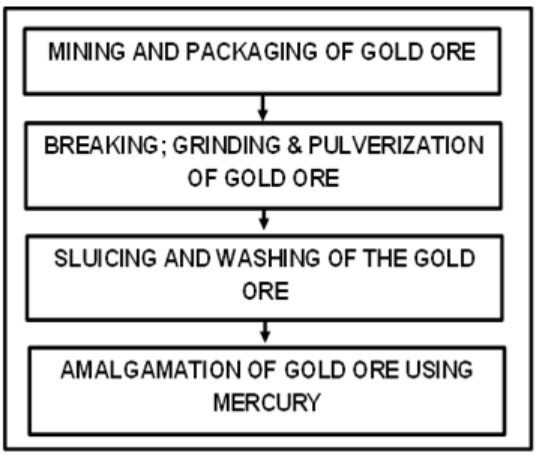

Fig. 1: Gold Processing Flowsheet as Reported by Miners

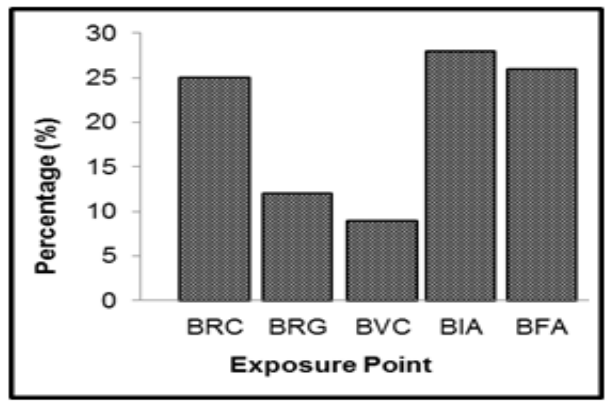

Fig. 2: Exposure Point to Lead Contaminated Soil in the Study Area

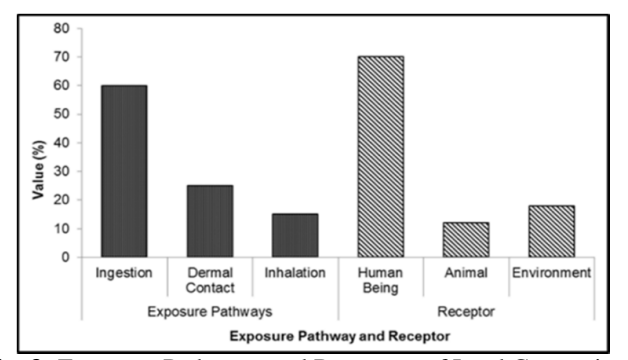

Fig. 3: Exposure Pathways and Receptors of Lead Contaminant

Table 3 shows the exposure pathways for cancer risk of lead metal in residential compounds. All the sampled residential compounds generates high carcinogenic lifetime risk for soil ingestion while dermal contact generates very low carcinogenic lifetime risk and that of inhalation is insignificant when compared with $1.00 \mathrm{E}-06 \mathrm{WHO}$ standard of cancer risk. It means that the lead pollution at residents of the study area posed a major cancer risk to the people and their environment through soil ingestion while sites BRC/06; BRC/07; BRC/08; BRC/09; $\mathrm{BRC} / 10$ and $\mathrm{BRC} / 11$ posed a minor cancer risk to the people and their environment through dermal contact and none of the sites posed risks to the people and their environment through inhalation. Therefore, those sites that posed cancer health risk to the people and their environment need to be monitored for further action. Table 4 establishes that only soil ingestion generates major high carcinogenic lifetime risk as their values above the WHO standard for cancer risk in the sampled residential garden. Meanwhile, sites BRG/02 and $\mathrm{BRG} / 03$ generate minor carcinogenic lifetime risk through dermal contact. Therefore, the people who work in the residential gardens were liable to be exposed to cancer risk through ingestion and dermal contact of lead contaminated soil. Table 5 illustrates that the sampled village common areas generates high carcinogenic lifetime risk for soil ingestion only as their values above the WHO standard for cancer risk. This justifies that people playing at village common areas were likely to be exposed to cancer risk through ingestion of lead contaminated soil at BVC. Table 6 shows that the only soil ingestion generates high carcinogenic lifetime risk in the sampled industrial areas as their values above the WHO standard for cancer risk. This established that the workers will be exposed to cancer risk through ingestion of lead contaminated soil and dust in industrial areas. It was discovered (Table 7) that all the sampled farmlands generates high carcinogenic lifetime risks of soil ingestion when compared with the WHO standard of acceptable risk. This established that the farmers will be exposed to cancer risk posed by lead pollution through ingestion of lead contaminated soil and dust at their farmlands. 
Table 3: Cancer Health Risk for Exposure Pathways at BRC

\begin{tabular}{lllll}
\hline ID & $\begin{array}{l}\text { Soil Ingestion } \\
(\mathrm{mg} / \mathrm{kg} / \text { day })\end{array}$ & $\begin{array}{l}\text { Dermal Contact } \\
(\mathrm{mg} / \mathrm{kg} / \mathrm{day})\end{array}$ & $\begin{array}{l}\text { Inhalation } \\
(\mathrm{mg} / \mathrm{kg} / \text { day })\end{array}$ & $\begin{array}{l}\text { Total } \\
(\mathrm{mg} / \mathrm{kg} / \mathrm{day})\end{array}$ \\
\hline $\mathrm{BRC} / 01$ & $9.11 \mathrm{E}-03$ & $2.87 \mathrm{E}-05$ & $5.40 \mathrm{E}-08$ & $9.14 \mathrm{E}-03$ \\
$\mathrm{BRC} / 02$ & $1.30 \mathrm{E}-02$ & $4.10 \mathrm{E}-05$ & $7.71 \mathrm{E}-08$ & $1.30 \mathrm{E}-02$ \\
$\mathrm{BRC} / 03$ & $1.29 \mathrm{E}-03$ & $4.07 \mathrm{E}-06$ & $7.65 \mathrm{E}-09$ & $1.29 \mathrm{E}-03$ \\
$\mathrm{BRC} / 04$ & $2.28 \mathrm{E}-03$ & $7.19 \mathrm{E}-06$ & $1.32 \mathrm{E}-08$ & $2.29 \mathrm{E}-03$ \\
$\mathrm{BRC} / 05$ & $1.93 \mathrm{E}-03$ & $6.08 \mathrm{E}-06$ & $1.14 \mathrm{E}-08$ & $1.94 \mathrm{E}-03$ \\
$\mathrm{BRC} / 06$ & $3.45 \mathrm{E}-03$ & $1.08 \mathrm{E}-05$ & $2.05 \mathrm{E}-08$ & $3.46 \mathrm{E}-03$ \\
$\mathrm{BRC} / 07$ & $3.63 \mathrm{E}-03$ & $1.14 \mathrm{E}-05$ & $2.16 \mathrm{E}-08$ & $3.64 \mathrm{E}-03$ \\
$\mathrm{BRC} / 08$ & $5.53 \mathrm{E}-03$ & $1.75 \mathrm{E}-05$ & $3.28 \mathrm{E}-08$ & $5.55 \mathrm{E}-03$ \\
$\mathrm{BRC} / 09$ & $3.71 \mathrm{E}-03$ & $1.17 \mathrm{E}-05$ & $2.20 \mathrm{E}-08$ & $3.72 \mathrm{E}-03$ \\
$\mathrm{BRC} / 10$ & $2.84 \mathrm{E}-02$ & $8.96 \mathrm{E}-05$ & $1.69 \mathrm{E}-07$ & $2.85 \mathrm{E}-02$ \\
$\mathrm{BRC} / 11$ & $3.38 \mathrm{E}-03$ & $1.06 \mathrm{E}-05$ & $2.01 \mathrm{E}-08$ & $3.39 \mathrm{E}-03$ \\
$\mathrm{BRC} / 12$ & $9.29 \mathrm{E}-03$ & $2.93 \mathrm{E}-06$ & $5.51 \mathrm{E}-09$ & $9.29 \mathrm{E}-03$ \\
$\mathrm{BRC} / 13$ & $1.92 \mathrm{E}-03$ & $6.08 \mathrm{E}-06$ & $1.14 \mathrm{E}-08$ & $1.93 \mathrm{E}-03$ \\
$\mathrm{BRC} / 14$ & $1.61 \mathrm{E}-03$ & $5.09 \mathrm{E}-06$ & $9.56 \mathrm{E}-09$ & $1.62 \mathrm{E}-03$ \\
$\mathrm{BRC} / 15$ & $1.10 \mathrm{E}-03$ & $3.48 \mathrm{E}-06$ & $6.54 \mathrm{E}-09$ & $1.10 \mathrm{E}-03$ \\
MEAN & $\mathbf{5 . 9 8 E - 0 3}$ & $\mathbf{1 . 7 1 E - 0 5}$ & $\mathbf{3 . 2 2 E}-08$ & $\mathbf{5 . 9 9 E}-03$ \\
\hline
\end{tabular}

Table 4: Cancer Health Risk for Exposure Pathways at BRG

\begin{tabular}{ccccc}
\multicolumn{4}{c}{ Table 4: Cancer Health Risk for Exposure Pathways at BRG } \\
\hline ID & $\begin{array}{c}\text { Soil } \\
\text { Ingestion } \\
(\mathrm{mg} / \mathrm{kg} / \mathrm{day})\end{array}$ & $\begin{array}{c}\text { Dermal } \\
\text { Contact } \\
(\mathrm{mg} / \mathrm{kg} / \mathrm{day})\end{array}$ & $\begin{array}{c}\text { Inhalation } \\
(\mathrm{mg} / \mathrm{kg} / \mathrm{day})\end{array}$ & $\begin{array}{c}\text { Total } \\
(\mathrm{mg} / \mathrm{kg} / \mathrm{day})\end{array}$ \\
\hline $\mathrm{BRG} / 01$ & $1.95 \mathrm{E}-03$ & $1.29 \mathrm{E}-05$ & $1.06 \mathrm{E}-07$ & $1.96 \mathrm{E}-03$ \\
$\mathrm{BRG} / 02$ & $7.95 \mathrm{E}-04$ & $5.24 \mathrm{E}-06$ & $4.32 \mathrm{E}-08$ & $8.00 \mathrm{E}-04$ \\
$\mathrm{BRG} / 03$ & $2.69 \mathrm{E}-03$ & $1.78 \mathrm{E}-05$ & $1.47 \mathrm{E}-07$ & $2.71 \mathrm{E}-03$ \\
$\mathrm{BRG} / 04$ & $9.91 \mathrm{E}-04$ & $6.54 \mathrm{E}-06$ & $5.39 \mathrm{E}-08$ & $9.98 \mathrm{E}-04$ \\
$\mathrm{BRG} / 05$ & $1.17 \mathrm{E}-03$ & $7.72 \mathrm{E}-06$ & $6.36 \mathrm{E}-08$ & $1.18 \mathrm{E}-03$ \\
MEAN & $\mathbf{1 . 5 2 E - 0 3}$ & $\mathbf{1 . 0 0 E - 0 5}$ & $\mathbf{8 . 2 7 E - 0 8}$ & $\mathbf{1 . 5 3 E - 0 3}$ \\
\hline
\end{tabular}

Table 5: Cancer Health Risk for Exposure Pathways at BVC

\begin{tabular}{ccccc}
\multicolumn{5}{c}{ Table 5: Cancer Health Risk for Exposure Pathways at BVC } \\
\hline ID & $\begin{array}{c}\text { Soil Ingestion } \\
(\mathrm{mg} / \mathrm{kg} / \text { day })\end{array}$ & $\begin{array}{c}\text { Dermal Contact } \\
(\mathrm{mg} / \mathrm{kg} / \mathrm{day})\end{array}$ & $\begin{array}{c}\text { Inhalation } \\
(\mathrm{mg} / \mathrm{kg} / \mathrm{day})\end{array}$ & $\begin{array}{c}\text { Total } \\
(\mathrm{mg} / \mathrm{kg} / \text { day })\end{array}$ \\
\hline BVC/01 & $4.70 \mathrm{E}-04$ & $1.61 \mathrm{E}-06$ & $2.56 \mathrm{E}-08$ & $4.72 \mathrm{E}-04$ \\
BVC/02 & $9.60 \mathrm{E}-04$ & $6.38 \mathrm{E}-06$ & $5.25 \mathrm{E}-08$ & $9.66 \mathrm{E}-04$ \\
BVC/03 & $1.92 \mathrm{E}-03$ & $1.26 \mathrm{E}-05$ & $1.04 \mathrm{E}-07$ & $1.93 \mathrm{E}-03$ \\
BVC/04 & $8.00 \mathrm{E}-04$ & $5.30 \mathrm{E}-06$ & $4.37 \mathrm{E}-08$ & $8.05 \mathrm{E}-04$ \\
BVC/05 & $2.19 \mathrm{E}-03$ & $1.45 \mathrm{E}-05$ & $1.19 \mathrm{E}-07$ & $2.20 \mathrm{E}-03$ \\
BVC/06 & $1.56 \mathrm{E}-03$ & $1.03 \mathrm{E}-05$ & $8.52 \mathrm{E}-08$ & $1.57 \mathrm{E}-03$ \\
BVC/07 & $4.30 \mathrm{E}-04$ & $2.86 \mathrm{E}-06$ & $2.35 \mathrm{E}-08$ & $4.33 \mathrm{E}-04$ \\
BVC/08 & $6.80 \mathrm{E}-04$ & $4.48 \mathrm{E}-06$ & $3.96 \mathrm{E}-08$ & $6.85 \mathrm{E}-04$ \\
BVC/09 & $2.60 \mathrm{E}-03$ & $1.72 \mathrm{E}-05$ & $1.41 \mathrm{E}-07$ & $2.62 \mathrm{E}-03$ \\
BVC/10 & $7.70 \mathrm{E}-04$ & $5.10 \mathrm{E}-06$ & $4.21 \mathrm{E}-08$ & $7.75 \mathrm{E}-04$ \\
BVC/11 & $3.71 \mathrm{E}-03$ & $2.45 \mathrm{E}-05$ & $2.02 \mathrm{E}-07$ & $3.73 \mathrm{E}-03$ \\
BVC/12 & $1.72 \mathrm{E}-03$ & $1.14 \mathrm{E}-05$ & $9.35 \mathrm{E}-08$ & $1.73 \mathrm{E}-03$ \\
MEAN & $\mathbf{1 . 4 8 E - 0 3}$ & $\mathbf{9 . 6 9 E - 0 6}$ & $\mathbf{8 . 1 0 E}-08$ & $\mathbf{1 . 4 9 E - 0 3}$ \\
\hline
\end{tabular}

\begin{tabular}{lllll}
\multicolumn{5}{c}{ Table 6: Cancer Health Risk for Exposure Pathways at BIA } \\
\hline ID & $\begin{array}{l}\text { Soil Ingestion } \\
(\mathrm{mg} / \mathrm{kg} / \mathrm{day})\end{array}$ & $\begin{array}{l}\text { Dermal Contact } \\
(\mathrm{mg} / \mathrm{kg} / \mathrm{day})\end{array}$ & $\begin{array}{l}\text { Inhalation } \\
(\mathrm{mg} / \mathrm{kg} / \mathrm{day})\end{array}$ & $\begin{array}{l}\text { Total } \\
(\mathrm{mg} / \mathrm{kg} / \mathrm{day})\end{array}$ \\
\hline BIA/01 & $3.64 \mathrm{E}-03$ & $2.40 \mathrm{E}-05$ & $1.98 \mathrm{E}-07$ & $3.66 \mathrm{E}-03$ \\
BIA/02 & $1.12 \mathrm{E}-03$ & $7.39 \mathrm{E}-06$ & $6.08 \mathrm{E}-08$ & $1.13 \mathrm{E}-03$ \\
BIA/03 & $5.26 \mathrm{E}-03$ & $3.47 \mathrm{E}-05$ & $2.86 \mathrm{E}-07$ & $5.29 \mathrm{E}-03$ \\
BIA/04 & $1.99 \mathrm{E}-03$ & $1.32 \mathrm{E}-05$ & $1.08 \mathrm{E}-07$ & $2.00 \mathrm{E}-03$ \\
BIA/05 & $5.53 \mathrm{E}-03$ & $3.66 \mathrm{E}-06$ & $3.02 \mathrm{E}-08$ & $5.53 \mathrm{E}-03$ \\
BIA/06 & $1.79 \mathrm{E}-03$ & $1.18 \mathrm{E}-05$ & $9.72 \mathrm{E}-08$ & $1.80 \mathrm{E}-03$ \\
BIA/07 & $7.85 \mathrm{E}-03$ & $5.18 \mathrm{E}-05$ & $4.26 \mathrm{E}-07$ & $7.90 \mathrm{E}-03$ \\
BIA/08 & $6.84 \mathrm{E}-03$ & $4.52 \mathrm{E}-05$ & $3.72 \mathrm{E}-07$ & $6.89 \mathrm{E}-03$ \\
BIA/09 & $5.41 \mathrm{E}-03$ & $3.57 \mathrm{E}-05$ & $2.94 \mathrm{E}-07$ & $5.45 \mathrm{E}-03$ \\
BIA/10 & $1.39 \mathrm{E}-03$ & $9.18 \mathrm{E}-06$ & $7.56 \mathrm{E}-08$ & $1.40 \mathrm{E}-03$ \\
BIA/11 & $5.72 \mathrm{E}-03$ & $3.77 \mathrm{E}-05$ & $3.11 \mathrm{E}-07$ & $5.76 \mathrm{E}-03$ \\
MEAN & $\mathbf{4 . 2 3 E - 0 3}$ & $\mathbf{2 . 4 9 E - 0 5}$ & $\mathbf{2 . 0 5 E - 0 7}$ & $\mathbf{4 . 2 6 E - 0 3}$ \\
\hline
\end{tabular}

The significance of health risk posed by the ingestion of lead contaminated soil as the major contributor to cancer health risk was tested with one sample t-test statistic in order to determine their levels of significance as shown in Table 8.

The respective p-values statistic for each site is less than 0.05 . The study therefore established that the mean value of soil ingested in each site posed a significant cancer health risk to the people of the study area. Also, the average mean difference of cancer health risk for each site when compared with 1.00E-06 WHO standard are in descending order of $\mathrm{BIA}<\mathrm{BRC}<\mathrm{BFA}<\mathrm{BRG}<$ BVC.

The health risk assessment model (HRAM) for the lead contaminated sites from the source of lead contaminant to the types of health risks posed to the people is presented in Figure 5. This was achieved by pulling together data obtained from questionnaire analyses; laboratory analyses and health risk analyses.

The source of lead contaminant was identified as artisanal gold mining as established in Table 2. Also, the lead released mechanism into the study area was given as breaking and grinding of gold ore, pulverization of gold, sluicing and washing of gold and amalgamation of gold as identified in Figure 1.

The potential environmental lead transport medium and their exposure points are: BRC, BRG, BVC, BIA and BFA as established in Figure 2.

Consequently, the major identified exposure pathways were given as ingestion, dermal contact and inhalation as identified in Figure 3. Meanwhile the receptor of lead exposure were human being, animal and environment and exposures risk is cancer risk as identified in Tables $2-8$. 
Table 7: Cancer Health Risk for Exposure Pathways at BFA

\begin{tabular}{lcccc}
\hline ID & $\begin{array}{c}\text { Soil Ingestion } \\
(\mathrm{mg} / \mathrm{kg} / \text { day })\end{array}$ & $\begin{array}{c}\text { Dermal Contact } \\
(\mathrm{mg} / \mathrm{kg} / \text { day })\end{array}$ & $\begin{array}{c}\text { Inhalation } \\
(\mathrm{mg} / \mathrm{kg} / \text { day })\end{array}$ & $\begin{array}{c}\text { Total } \\
(\mathrm{mg} / \mathrm{kg} / \mathrm{day})\end{array}$ \\
\hline BFA/01 & $5.90 \mathrm{E}-04$ & $3.93 \mathrm{E}-06$ & $3.24 \mathrm{E}-08$ & $5.94 \mathrm{E}-04$ \\
BFA/02 & $3.95 \mathrm{E}-03$ & $2.61 \mathrm{E}-05$ & $2.15 \mathrm{E}-07$ & $3.98 \mathrm{E}-03$ \\
BFA/03 & $4.50 \mathrm{E}-04$ & $2.99 \mathrm{E}-05$ & $2.47 \mathrm{E}-08$ & $4.80 \mathrm{E}-04$ \\
BFA/04 & $3.09 \mathrm{E}-03$ & $2.01 \mathrm{E}-05$ & $1.66 \mathrm{E}-07$ & $3.11 \mathrm{E}-03$ \\
BFA/05 & $1.67 \mathrm{E}-03$ & $1.10 \mathrm{E}-05$ & $9.08 \mathrm{E}-08$ & $1.68 \mathrm{E}-03$ \\
BFA/06 & $2.21 \mathrm{E}-03$ & $1.46 \mathrm{E}-05$ & $1.20 \mathrm{E}-07$ & $2.22 \mathrm{E}-03$ \\
BFA/07 & $5.67 \mathrm{E}-03$ & $3.74 \mathrm{E}-05$ & $3.08 \mathrm{E}-07$ & $5.71 \mathrm{E}-03$ \\
BFA/08 & $6.72 \mathrm{E}-03$ & $4.43 \mathrm{E}-05$ & $3.66 \mathrm{E}-07$ & $6.76 \mathrm{E}-03$ \\
MEAN & $\mathbf{3 . 0 4 E - 0 3}$ & $\mathbf{2 . 3 4 E - 0 5}$ & $\mathbf{1 . 6 5 E}-07$ & $\mathbf{3 . 0 7 E - 0 3}$ \\
\hline
\end{tabular}

Table 8: One Sample t-test Statistic for Soil Ingestion Test Value $=0.000001$

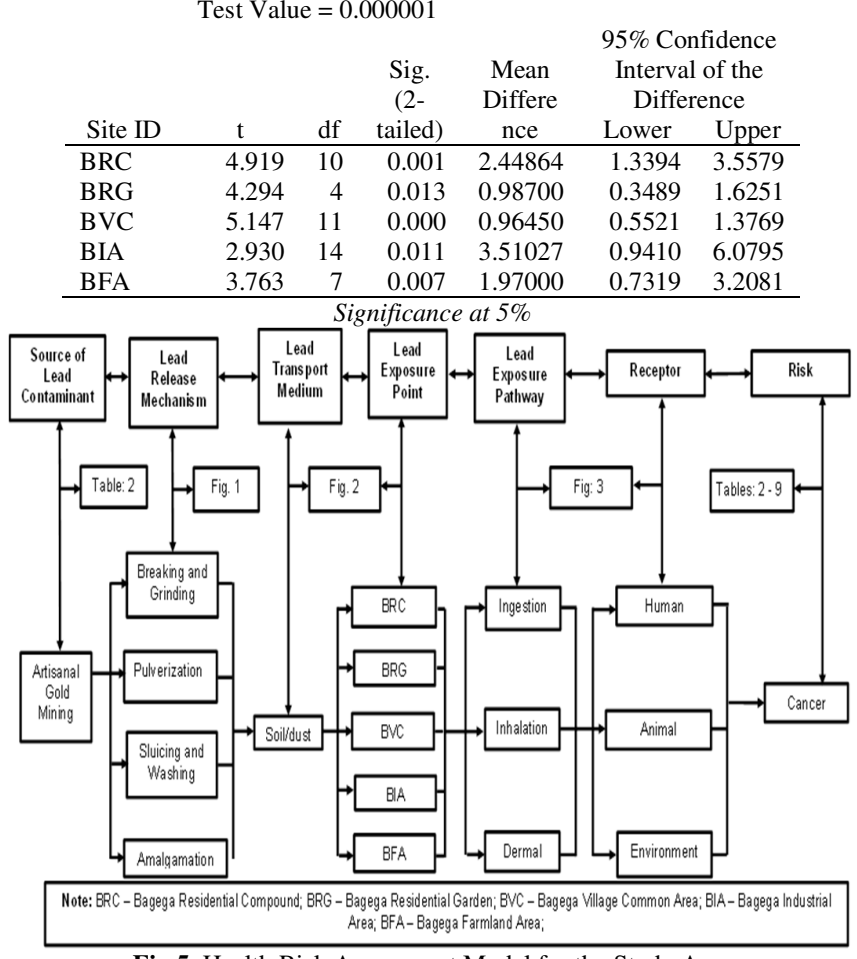

Fig 5: Health Risk Assessment Model for the Study Area

Conclusion: The study has successfully developed heath risk assessment model for lead contaminated soil. It was revealed that soil ingestion generates high cancer risk while dermal contact generates average cancer risk and that of inhalation was insignificant when compared with WHO standard for cancer risk. The testing of the significance of health risk justified that the cancer health risk in soil sample posed a significant health risk to the people of the study area. The study therefore established the importance of health risk assessment model in facilitating the selection and effectiveness of remedial options.

\section{REFERENCES}

Alaba, OC; Adesida, AP (2017). Health risk ranking of lead contaminated sites in Bagega Community, Zamfara State, Nigeria. J Hum Environ Health Promot. 2(4): 201-11.
Alaba, OC; Opafunso, ZO (2016). Environmental assessment of lead contaminated site from artisanal gold mining in Bagega Community, Nigeria. Archives of Current Research International. 5(4): 1-9.

ASTM D3559. Standard test method for lead metals in soil. Available https://www.astm.org/Standard s/D3559.htm\#_ga=1.90023582 .486872062 .1378841048 .

ASTM D6907. Standard practice for sampling soils and contaminated media with handoperated bucket augers. Available at https://www.astm.org/Standard s/D6907.htm\#_ga=1.91236895 .486872062 .1378841048 .

Bello, O; Naidu, R; Rahman, MM; Liu, Y; Dong, Z (2016): Lead concentration in the blood of the general population living near a lead-zinc mine site, Nigeria: Exposure pathways. Sci Total Environ, 542(A): 908914.

Centers for Disease Control and Prevention (CDC) (2010). Outbreak of acute lead poisoning among children aged $<5$ years-Zamfara, Nigeria. MMWR Morb Mortal Wkly Rep. Available at http://www.cdc.gov/mmwr/ preview/mmwrhtml/mm5927a 3.htm?s_cid=mm5927a3_w.

Canadian Standards Association (CSA), (2001). CSA Standard Z768-01 Phase I environmental site assessment, CSA. Canada.

Greig, J; Thurtle, N; Cooney, L; Ariti, C; Ahmed, AO; Ashagre, $\mathrm{T}$ (2014). Association of Blood Lead Level with Neurological Features in 972 Children 
Affected by an Acute Severe Lead Poisoning Outbreak in Zamfara State, Northern Nigeria. Available: doi: 10.1371/journal.pone.0093716.

Human Rights Watch (HRW) (2011): A Heavy Price: Lead poisoning and Gold Mining in Nigeria's Zamfara State. New York: Human Rights Watch. Available: http://www.hrw.org/features/a-heavyprice.

Joint United Nations Environment Programme/Office for the Coordination of Humanitarian Affairs (JUNEP/OCHA) (2010). Lead Pollution and Poisoning Crisis - Environmental Emergency Response Mission, Zamfara State, Nigeria. Available at http://www.unocha.org/what-wedo/coordinationtools/environmental-emergencies/resources.

Medecins Sans Frontieres (MSF) (2012). Lead Poisoning Crisis in Zamfara State Northern Nigeria. MSF Brief Pap. Available at http://www.msf.org/sites/msf.org/files/old-cms/fms/articledocuments/MSF-Nigeria-Lead.pdf.

Taiwo, AM; Awomeso, JA (2017). Assessment of trace metal concentration and health risk of artisanal gold mining activities in Ijeshaland, Osun State Nigeria- Part 1. J Geochem Explor. 177: 110.
United States Environmental Protection Agency (USEPA) (1989). Guidance for conducting remedial investigations and feasibility studies under CERCLA. OSWER Directive 9355.3-0.

United States Environmental Protection Agency (USEPA) (1991): Risk assessment guidance for superfund, volume 1, human health evaluation manual, Part B, Development of Risk-based Preliminary Remediation Goals. EPA 9285. 7-01B.

World Health Organization (WHO) (1994): Assessing human health risks of chemicals: derivation of guidance values for health based exposure limits. International Programme on Chemical Safety, Environmental Health Criteria, 170, Geneva, Switzerland. 